\title{
Penyelesaian Masalah Economic Dispatch Menggunakan Equilibrium Optimizer
}

\author{
Osea Zebua $^{1 *}$, I Made Ginarsa ${ }^{2}$, dan I Made Ari Nrartha ${ }^{2}$ \\ ${ }^{1}$ Jurusan Teknik Elektro, Fakultas Teknik, Universitas Lampung \\ Jl. Prof. S. Brojonegoro no.1 Bandarlampung, 35145, Indonesia \\ ${ }^{2}$ Jurusan Teknik Elektro, Fakultas Teknik, Universitas Mataram \\ Jl. Majapahit no.62, Mataram, 83125, Indonesia \\ *Corresponding author. Email: osea.zebua@eng.unila.ac.id
}

\begin{abstract}
This paper presents a metaheuristic method, namely Equilibrium Optimizer (EO) to solve the economic dispatch (ED) problem. The main objective function to be achieved is to minimize the total fuel costs of all generating units to meet the total load demand and to satisfy various operating constraints. Three case studies are used to test the effectiveness of the EO method in solving ED problems, they are three generators case, six generators case, and fifteen generators case. The simulation of solving ED problems using the EO method is implemented using MATLAB software and is carried out 30 times for each case study. The results of EO method are compared with Particle Swarm Optimization (PSO), Grey Wolf Optimizer (GWO), and Whale Optimization Algorithm (WOA) methods. The simulation results show that the EO method can solve the ED problem more optimal than all other comparison methods for all the case studies by producing the minimum total fuel costs.
\end{abstract}

Keywords-economic dispatch, minimization, fuel cost function, equilibrium optimizer

\begin{abstract}
Abstrak- Makalah ini menyajikan suatu metode metaheuristik, yakni Equilibrium Optimizer (EO) untuk menyelesaikan masalah economic dispatch (ED). Fungsi tujuan utama yang ingin dicapai adalah meminimalkan total biaya bahan bakar semua unit pembangkit untuk memenuhi kebutuhan beban total dan memenuhi berbagai batasan operasi. Tiga studi kasus digunakan untuk menguji keefektifan metode EO dalam menyelesaikan masalah ED, yakni kasus dengan 3 generator, kasus dengan 6 generator, dan kasus dengan 15 generator. Simulasi penyelesaian ED menggunakan metode EO diimplementasikan menggunakan perangkat lunak MATLAB dan dilakukan sebanyak 30 kali untuk setiap studi kasus. Hasil penyelesaian menggunakan metode EO dibandingkan dengan hasil penyelesaian menggunakan metode Particle Swarm Optimization (PSO), Grey Wolf Optimizer (GWO), dan Whale Optimization Algorithm (WOA). Hasil simulasi menunjukkan bahwa metode EO dapat menyelesaikan masalah ED lebih optimal daripada semua metode perbandingan lainnya untuk semua studi kasus dengan menghasilkan biaya bahan bakar total yang paling minimum.
\end{abstract}

Kata kunci-economic dispatch, minimisasi, fungsi biaya bahan bakar, equilibrium optimizer

\section{Pendahuluan}

Masalah economic dispatch (ED) menjadi masalah yang penting dalam operasi dan perencanaan dari sistem tenaga listrik yang modern. Masalah ED didefenisikan sebagai masalah penentuan penjadwalan pembangkitan daya dengan biaya paling minimum dari sekumpulan unit pembangkit listrik yang beroperasi untuk melayani beban. Tujuan utama dari ED adalah untuk meminimalkan biaya total operasi semua unit pembangkit yang online dengan memenuhi berbagai batasan (constraint) operasi [1].

Dalam masalah ED, karakteristik input-output (atau fungsi biaya) dari generator biasanya direpresentasikan dengan menggunakan fungsi kuadratik yang halus (smooth) [2]. Namun secara praktis, batas kenaikan dan penurunan beban (ramp rate) serta batas daerah operasi generator yang tidak diperbolehkan (prohibited operation zone) membuat fungsi biaya menjadi tidak kontinyu [3]. Adanya efek titik pembebanan katup (valve loading-point effect) juga membuat fungsi biaya menjadi tidak konveks. Dengan mempertimbangkan penggunaan jenis bahan bakar yang bervariasi (multiple fuel) dan biaya emisi minimum yang dihasilkan mengubah masalah ED menjadi masalah optimasi yang tidak konveks dengan banyak batasan [4].

Penyelesaian ED menggunakan algoritma matematika tradisional, seperti algoritma berbasis metode gradien, relaksasi Lagrange, iterasi lamda, branch and bound, pemrograman linier, pemrograman kuadratik, dan pemrograman dinamis tidak dapat menyelesaikan masalah ED dengan baik, karena karakteristik yang sangat tidak linier dan tidak konveks dari permasalahan ED [5]. Beberapa metode berbasis algoritma matematika ini telah diperbaharui untuk memperoleh hasil penyelesaian yang lebih baik [6], [7].

Metode berbasis heuristik dan metaheuristik tidak dipengaruhi oleh ketidaklinieran, tidak kontinyu, dan tidak konveks. Metode ini memiliki keunggulan dalam kemampuan pencarian secara global, penanganan berbagai batasan yang lebih efektif, kebutuhan informasi yang minimum dan kinerja

Received 25 January 2021, Accepted 7 June 2021, Published 20 June 2021.

DOI: https://doi.org/10.15294/jte.v13i1.28698 
yang andal, membuatnya lebih potensial untuk menyelesaikan masalah ED. Berbagai metode heuristik dan metaheuristik telah diusulkan dan diaplikasikan dalam penyelesaian masalah ED dengan mempertimbangkan karakteristik ramp-rate (RR) dan prohibited operating zone (POZ) [8], karakteristik RR, POZ dan valve loading-point effect (VPE) [9], [10], karakteristik RR, POZ, VPE, dan multiple fuel (MF) [11] [13], karakteristik VPE [14], karakteristik VPE dan biaya emisi minimum (EM) [15], karakteristik VPE dan MF [16], [17], serta karakteristik RR, VPE, dan MF [18], [19].

Pentingnya penyelesaian masalah ED dengan berbagai karakteristik input-output dari generator, membutuhkan metode optimisasi yang cepat dan handal serta menghasikan penyelesaian yang lebih optimal. Makalah ini menyajikan penyelesaian ED menggunakan metode Equilibrium Optimizer (EO). EO adalah suatu teknik optimisasi metaheuristik berbasis proses fisika yang terinspirasi dari proses keseimbangan massa dalam sistem kontrol volume [20]. Metode EO telah diuji coba dalam beberapa permasalahan optimisasi dan memiliki akurasi yang lebih baik serta konvergensi yang lebih cepat dibandingkan dengan beberapa metode metaheuristik lainnya [21], [22].

Pada makalah ini, fungsi biaya yang dianalisis adalah hanya fungsi biaya kuadratik yang halus, tanpa atau dengan mempertimbangkan batasan operasi RR dan POZ serta rugirugi saluran transmisi. Penggunaan metode EO diharapkan dapat memberikan penyelesaian ED dengan nilai optimal yang lebih baik dan konvergensi yang lebih cepat. Hasil penyelesaian dengan menggunakan metode EO dibandingkan dengan penyelesaian dengan beberapa metode heuristik lainnya, antara lain: Particle Swarm Optimization (PSO) [23], [24], Grey Wolf Optimizer (GWO) [25], [26], dan Whale Optimization Algorithm (WOA) [27].

\section{METODE}

\section{A. Formulasi Masalah ED}

Masalah ED adalah masalah untuk menentukan tingkat daya nyata pembangkit listrik yang paling optimal untuk semua unit pembangkit dengan memenuhi kebutuhan beban dalam sistem tenaga. Implementasi penyelesaian masalah ED harus memenuhi berbagai batasan dari operasi pembangkit. Tujuan utama dari masalah ED adalah meminimalkan biaya bahan bakar total $\left(F_{T}\right)$ dan dapat dirumuskan sebagai proses optimisasi [28], yakni:

$$
\min F_{T}=\min \sum_{i=1}^{N} F_{i}\left(P_{i}\right)
$$

di mana $F_{i}$ adalah fungsi biaya bahan bakar pada beban $P$ dari unit pembangkit ke- $i$ dan $N$ adalah jumlah unit pembangkit dalam sistem. Fungsi biaya bahan bakar ini biasanya dinyatakan dengan fungsi kuadratik yang halus seperti ditunjukkan pada Gambar 1, dengan persamaan:

$$
F_{i}\left(P_{i}\right)=a_{i} P_{i}^{2}+b_{i} P_{i}+c_{i}
$$

di mana $a_{i}, b_{i}$ and $c_{i}$ adalah koefisien biaya bahan bakar dari unit pembangkit ke- $i$. Dengan mempertimbangkan POZ, maka kurva biaya bahan bakar menjadi tidak kontinyu seperti ditunjukkan pada Gambar 2.

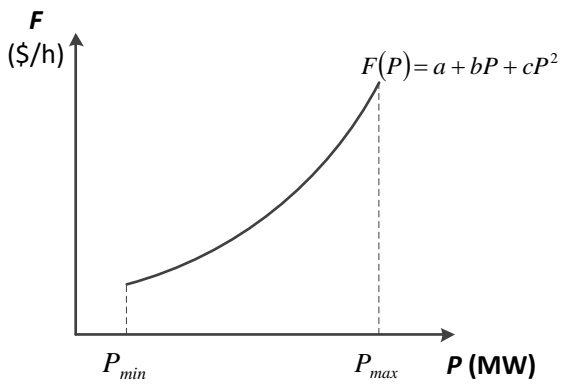

Gambar 1. Fungsi biaya bahan bakar kuadratik

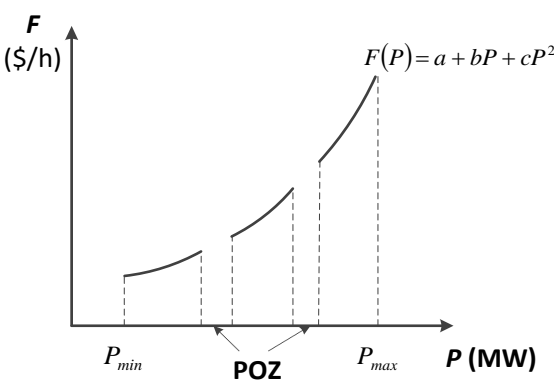

Gambar 2. Fungsi biaya bahan bakar kuadratik dengan POZ

Penyelesaian masalah ED dari unit pembangkit untuk melayani kebutuhan beban harus memenuhi batasan-batasan persamaan dan pertidaksamaan, antara lain:

1. Batasan keseimbangan daya

$$
\sum_{i=1}^{N} P_{i}-P_{D}-P_{\text {loss }}=0
$$

di mana $P_{D}$ adalah beban total dan $P_{\text {loss }}$ adalah rugi-rugi transmisi total. $P_{\text {loss }}$ dapat dihitung menggunakan matriks koefisien rugi-rugi, $B$-loss, yang dinyatakan dengan persamaan:

$$
P_{\text {loss }}=\sum_{i=1}^{N} \sum_{i=1}^{N} P_{i} B_{i j} P_{j}+\sum_{i=n}^{N} B_{i} P_{i}+B_{00}
$$

2. Batasan kapasitas pembangkitan

$$
P_{g i}{ }^{\min } \leq P_{g i} \leq P_{g i}^{\max }
$$

di mana $P_{g i}^{\min }$ dan $P_{g i}^{\max }$ masing-masing adalah daya output minimum dan maksimum dari unit generator ke- $i$.

3. Batasan ramp rate generator

$$
\begin{gathered}
\operatorname{Max}\left(P_{g i}{ }^{\min }, P_{g i}{ }^{0}-D R_{i}\right) \leq P_{g i} \leq \min \left(P_{g i}{ }^{\max }, P_{g i}{ }^{0}+U R_{i}\right) \\
i=1,2, \ldots, n_{g}
\end{gathered}
$$

di mana $P_{g i}^{0}$ adalah titik operasi awal generator $i, D R_{i}$ and

$U R_{i}$ masing-masing adalah batas down ramp dan up ramp dari generator $i$.

4. Daerah operasi generator yang tidak diperbolehkan (POZ)

$$
P_{g i}=\left\{\begin{array}{c}
P_{g i}{ }^{\min } \leq P_{g i} \leq P_{g i, 1}{ }^{L B} \\
P_{g i, j-1}{ }^{U B} \leq P_{g i} \leq P_{g i, j}{ }^{L B} \\
P_{g i, n_{j}}{ }^{U B} \leq P_{g i} \leq P_{g i}{ }^{\max }
\end{array} \quad j=2,3, \ldots, n_{j} .\right.
$$

di mana $P_{g i}^{L B}$ dan $P_{g i}^{U B}$ masing-masing adalah batas bawah dan batas atas dari POZ dari unit ke- $i$ sedangkan $n_{j}$ adalah jumlah POZ. 


\section{B. Implementasi Metode EO dalam Penyelesaian ED}

Pada sistem kontrol volume, massa mencapai keadaan seimbang (equilibrium) bila massa yang keluar dari sistem sama dengan massa yang masuk ke sistem ditambah dengan massa yang dibangkitkan di dalam sistem dan dapat dinyatakan dengan persamaan [29]:

$$
C=C_{e q}+\left(C_{0}-C_{e q}\right) F+\frac{G}{\lambda V}(1-F)
$$

di mana $C$ adalah konsentrasi akhir, $C_{e q}$ adalah konsentrasi pada keadaan seimbang, $C_{0}$ adalah konsentrasi awal, $G$ adalah generation rate (tingkat generasi), $\lambda$ adalah turnover rate, $V$ adalah volume, dan $F$ adalah exponential term (bagian eksponensial). Exponential term $F$ dapat dihitung dengan persamaan:

$$
F=e^{-\lambda\left(t-t_{0}\right)}
$$

di mana $t_{0}$ adalah waktu start awal.

Tiga bagian pada (8) mempunyai efek terhadap pencarian dan pembaharuan dari metode EO. EO menggunakan partikelpartikel sebagai suatu penyelesaian dan posisi partikel sebagai konsentrasi. Tahap-tahap dalam algoritma EO dijelaskan berikut ini:

\section{1) Inisialisasi dan Evaluasi Fitness (Fungsi Objektif)}

Inisialisasi dilakukan dengan membuat suatu populasi awal dari partikel. Posisi partikel-partikel dibuat secara acak dengan memenuhi persamaan:

$$
C_{i}^{\text {awal }}=C_{\text {min }}+\operatorname{rand}_{i}\left(C_{\text {max }}-C_{\text {min }}\right) \quad i=1,2, \ldots, N \text {. (10) }
$$

di mana $C_{i}{ }^{\text {awal }}$ adalah konsentrasi awal dari partikel $i, C_{\min }$ dan $C_{\text {max }}$ masing-masing adalah nilai minimum dan nilai maksimum dari konsentrasi, rand $_{i}$ adalah bilangan acak antara 0 dan 1, sedangkan $N$ adalah jumlah partikel.

\section{2) Equilibrium Pool dan Candidates}

Pada keadaan seimbang, metode EO membentuk suatu vektor yang disebut dengan equilibrium pool dan berisikan 5 kandidat equilibrium (equilibrium candidate). Empat kandidat diperoleh dari empat partikel yang menghasilkan nilai fitness terbaik. Satu partikel lainnya diperoleh dengan mengambil nilai rata-rata aritmetik dari keempat partikel tersebut. Vektor dari equilibrium pool dinyatakan dengan persamaan:

$$
\vec{C}_{e q, p}=\left[\vec{C}_{e q 1}, \vec{C}_{e q 2}, \vec{C}_{e q 3}, \vec{C}_{e q 4}, \vec{C}_{e q, a v e}\right]
$$

di mana $\vec{C}_{e q, a v e}$ dihitung dengan:

$$
\vec{C}_{e q, a v e}=\frac{\vec{C}_{e q 1}+\vec{C}_{e q 2}+\vec{C}_{e q 3}+\vec{C}_{e q 4}}{4}
$$

\section{3) Update Konsentrasi}

Exponential term $F$ dan generation rate $G$ memegang peranan penting dalam eksplorasi dan eksploitasi metode EO selama proses update konsentrasi. Waktu $t$ pada (9) merupakan fungsi iterasi yang nilainya menurun terhadap jumlah iterasi, yakni:

$$
t=\left(1-\frac{\text { iter }}{\text { iter }_{\max }}\right)^{a_{2} \frac{\text { iter }}{\text { itermax }}}
$$

Perhitungan $t_{0}$ dilakukan sebagai berikut:

$$
\vec{t}_{0}=\frac{1}{\vec{\lambda}} \ln \left(-a_{1} \operatorname{sign}(\vec{r}-0,5)\left[1-e^{-\vec{\lambda} t}\right]\right)+t
$$

di mana $a_{1}$ dan $a_{2}$ masing-masing adalah konstanta kontrol eksplorasi dan kontrol eksploitasi, $\vec{r}$ adalah vektor acak dengan nilai pada interval $[0,1]$, dan $\operatorname{sign}(\vec{r}-0,5)$ menentukan arah eksplorasi dan eksploitasi dari metode EO. Semakin besar nilai $a_{1}$, maka semakin besar kemampuan eksplorasi dan semakin kecil kemampuan eksploitasi. Sebaliknya, jika semakin besar nilai $a_{2}$, maka semakin besar kemampuan eksploitasi dan semakin kecil kemampuan eksplorasi.

Dengan memasukkan (13) dan (14) pada (9), maka diperoleh:

$$
\vec{F}=a_{1} \operatorname{sign}(\vec{r}-0,5)\left[e^{-\vec{\lambda} t}-1\right]
$$

Generation rate, $\vec{G}$, memperbaiki kemampuan eksploitasi metode EO dan dihitung dengan:

$$
\vec{G}=\vec{G}_{0} \vec{F}
$$

dengan,

$$
\begin{gathered}
\vec{G}_{0}=\overrightarrow{G C P}\left(\vec{C}_{e q}-\vec{\lambda} \vec{C}\right) \\
\overrightarrow{G C P}= \begin{cases}0,5 r_{1}, & r_{2} \geq G P \\
0, & r_{2} \leq G P\end{cases}
\end{gathered}
$$

di mana $r_{1}$ dan $r_{2}$ adalah bilangan acak dalam interval [0,1], $\overrightarrow{G C P}$ adalah generation control parameter, dan GP adalah generation probability.

Update konsentrasi dilakukan dengan persamaan:

$$
\vec{C}=\vec{C}_{e q}+\left(\vec{C}-\vec{C}_{e q}\right) \vec{F}+\frac{\vec{G}}{\vec{\lambda} V}(1-\vec{F})
$$

di mana volume $V$ bernilai 1 .

Langkah-langkah algoritma EO untuk menyelesaikan permasalahan ED diringkaskan sebagai berikut:

1. Masukkan data setiap unit generator, seperti koefisien biaya bahan bakar, batas minimum dan batas maksium pembangkitan, batas-batas ramp rate, dan $\mathrm{POZ}$.

2. Tentukan parameter kontrol $a_{1}$ dan $a_{2}$, generation probability $G$, jumlah dimensi pencarian, jumlah iterasi maksimum itermax, dan jumlah partikel.

3. Buat populasi awal yang acak dari partikel (Persamaan (10)).

4. Evaluasi nilai fitness dan konsentrasi (posisi) setiap partikel.

5. Bentuk equilibrium pool dan kandidat equilibrium (Persamaan (11)). Simpan semua hasil terbaik dalam memori (memory saving).

6. Tentukan waktu $t$ (Persamaan (13))

7. Pilih satu kandidat secara acak dari equilibrium pool untuk setiap partikel. Hasilkan turnover rate $\vec{\lambda}$ dan bilangan $\vec{r}$ secara acak.

8. Konstruksikan exponential term $\vec{F}$ (Persamaan (15)).

9. Konstruksikan generation rate awal $\vec{G}_{o}$ (Persamaan (17)) dan parameter generation control $\overrightarrow{G C P}$ (Persamaan (18)).

10. Konstruksikan generation rate $\vec{G}$ (Persamaan (16)).

11. Update konsentrasi setiap partikel (Persamaan (19)).

12. Naikkan nilai iterasi, iter $=$ iter +1 . Jika nilai iterasi lebih kecil dari jumlah iterasi maksimum, lakukan langkah 4 sampai 11. Jika tidak, cetak hasil fitness, dan konsentrasi partikel.

Bagan alir dari metode EO dalam penyelesaian ED ditunjukkan pada Gambar 3. 
Januari - Juni 2021

\section{Studi Kasus}

Tiga studi kasus digunakan untuk menguji efektifitas metode EO dalam penyelesaian masalah ED. Ketiga studi kasus menjelaskan penyelesaian ED dengan pertimbangan kondisi sistem yang berbeda-beda. Data koefisien biaya bahan bakar, batasan operasi generator, yakni batas-batas RR dan POZ serta koefisien rugi-rugi untuk semua studi kasus diperoleh dari [11]
Studi kasus 1: Kasus ini menggunakan fungsi biaya bahan bakar yang halus dengan hanya mempertimbangkan batasan keseimbangan daya dan kapasitas pembangkitan setiap unit generator. Batasan operasi generator dan rugi-rugi saluran transmisi diabaikan. Kasus ini terdiri dari 3 generator dengan beban total sebesar 850 MW. Data koefisien fungsi biaya bahan bakar ditunjukkan pada Tabel I.

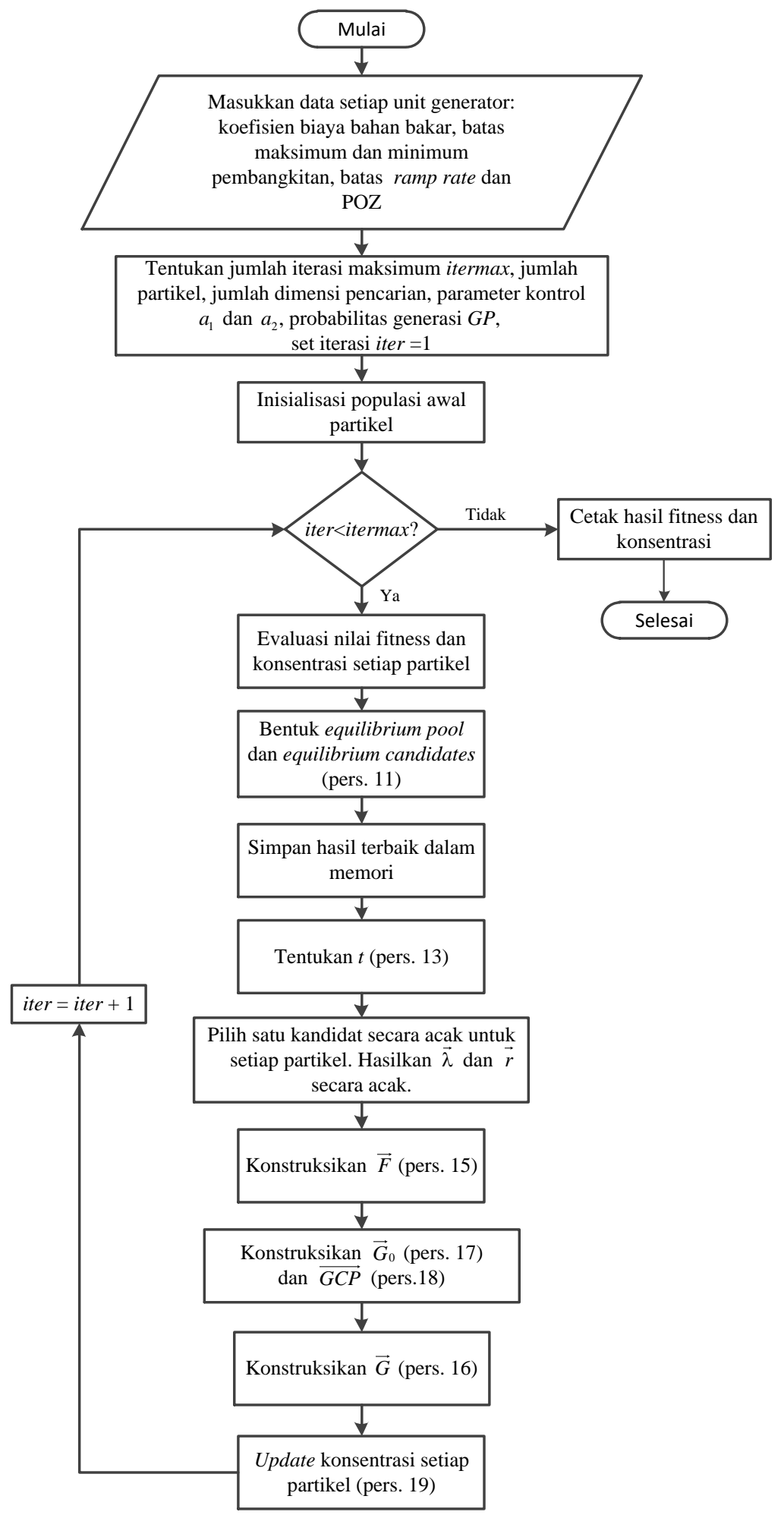

Gambar 3. Bagan alir metode EO dalam penyelesaian ED 
TABEL I. KARAKTERISTIK UNIT GENERATOR STUDI KASUS 1

\begin{tabular}{|c|c|c|c|c|c|}
\hline Unit & $\begin{array}{c}P_{g i}^{\min } \\
(\mathbf{M W})\end{array}$ & $\begin{array}{c}P_{g i}^{\max } \\
(\mathbf{M W})\end{array}$ & $\begin{array}{c}a_{i} \\
\left(\$ / \mathbf{M W}^{2}\right)\end{array}$ & $\begin{array}{c}b_{i} \\
(\$ / M W)\end{array}$ & $\begin{array}{c}c_{i} \\
(\$)\end{array}$ \\
\hline 1 & 100 & 600 & 0,001562 & 7,92 & 561 \\
\hline 2 & 100 & 400 & 0,001940 & 7,85 & 310 \\
\hline 3 & 50 & 200 & 0,004820 & 7,97 & 78 \\
\hline
\end{tabular}

Studi kasus 2: Kasus ini menggunakan fungsi biaya bahan bakar yang halus dengan mempertimbangkan batasan keseimbangan daya, batasan kapasitas pembangkitan setiap unit generator, batasan operasi generator, dan rugi-rugi saluran transmisi. Kasus ini terdiri dari 6 generator termal, 26 bus, dan 46 saluran transmisi dengan beban total sebesar 1263 MW [30]. Data koefisien biaya bahan bakar, batas-batas RR, dan POZ ditunjukkan pada Tabel II. Rugi-rugi saluran transmisi dihitung dengan menggunakan (4), di mana koefisien rugi-rugi, $B_{i j}, B_{0 i}$, dan $B_{00}$ diberikan pada (20).

Studi kasus 3: Kasus ini juga menggunakan fungsi biaya bahan bakar yang halus dengan mempertimbangkan batasan keseimbangan daya, batasan kapasitas pembangkitan setiap unit generator, batasan operasi generator, dan rugi-rugi saluran transmisi. Kasus ini terdiri dari 15 generator dan mempunyai beban total sebesar 2630 MW. Data koefisien biaya bahan bakar, batas-batas RR, dan POZ ditunjukkan pada Tabel III. Koefisien rugi-rugi, $B_{i j}, B_{0 i}$, dan $B_{00}$ untuk menghitung rugi-rugi saluran transmisi dengan menggunakan (4), diberikan pada (21).

TABEL II. KARAKTERISTIK UNIT GENERATOR STUdI KASUS 2

\begin{tabular}{|c|c|c|c|c|c|c|c|c|c|}
\hline Unit & $\begin{array}{c}P_{g i}^{\min } \\
(\mathbf{M W})\end{array}$ & $\begin{array}{l}P_{g i}^{\max } \\
(\mathbf{M W})\end{array}$ & $\begin{array}{c}a_{i} \\
\left(\$ / \mathbf{M W}^{2}\right)\end{array}$ & $\begin{array}{c}b_{i} \\
(\$ / M W)\end{array}$ & $\begin{array}{c}c_{i} \\
(\$ / \mathbf{M W})\end{array}$ & $\begin{array}{c}D R_{i} \\
(\mathbf{M W} / \mathbf{h})\end{array}$ & $\begin{array}{c}U R_{i} \\
(\mathbf{M W / h})\end{array}$ & $\begin{array}{c}P_{g i}^{0} \\
(\mathbf{M W})\end{array}$ & $\begin{array}{c}\text { Prohibited operating } \\
\text { zone }(\mathrm{POZ})\end{array}$ \\
\hline 1 & 100 & 500 & 0,0070 & 7,0 & 240 & 120 & 80 & 440 & {$\left[\begin{array}{lll}210 & 240\end{array}\right]\left[\begin{array}{lll}350 & 380\end{array}\right]$} \\
\hline 2 & 50 & 200 & 0,0095 & 10,0 & 200 & 90 & 50 & 170 & {$\left[\begin{array}{lll}90 & 110]\end{array}\left[\begin{array}{lll}140 & 160\end{array}\right]\right.$} \\
\hline 3 & 80 & 300 & 0,0090 & 8,5 & 220 & 100 & 65 & 200 & {$\left[\begin{array}{lll}150 & 170\end{array}\right]\left[\begin{array}{lll}210 & 240\end{array}\right]$} \\
\hline 4 & 50 & 150 & 0,0090 & 11,0 & 200 & 90 & 50 & 150 & [80 90] [110 120] \\
\hline 5 & 50 & 200 & 0,0080 & 10,5 & 220 & 90 & 50 & 190 & {$\left[\begin{array}{ll}90 & 110\end{array}\right]\left[\begin{array}{ll}140 & 150\end{array}\right]$} \\
\hline 6 & 50 & 120 & 0,0075 & 12,0 & 190 & 90 & 50 & 110 & {$\left[\begin{array}{ll}75 & 85\end{array}\right]\left[\begin{array}{ll}100 & 105\end{array}\right]$} \\
\hline
\end{tabular}

$$
\begin{aligned}
& B_{i j}=\left[\begin{array}{cccccc}
0,000017 & 0,000012 & 0,000007 & -0,000001 & -0,000005 & -0,000002 \\
0,000012 & 0,000014 & 0,000009 & 0,000001 & -0,000006 & -0,000001 \\
0,000007 & 0,000009 & 0,000031 & 0,000000 & -0,000010 & -0,000006 \\
-0,000001 & 0,000001 & 0,000000 & 0,000024 & -0,000006 & -0,000008 \\
-0,000005 & -0,000006 & -0,000010 & -0,000006 & 0,000120 & -0,000002 \\
-0,000002 & -0,000001 & -0,000006 & -0,000008 & -0,000002 & 0,000150
\end{array}\right] \\
& B_{0 i}=10^{-3} *\left[\begin{array}{llllll}
-0,3908 & -0,1297 & 0,7047 & 0,0591 & 0,2161 & -0,6635
\end{array}\right] \\
& B_{00}=0,0056
\end{aligned}
$$

\begin{tabular}{|c|c|c|c|c|c|c|c|c|c|}
\hline Unit & $\begin{array}{l}P_{g i}^{\min } \\
(\mathbf{M W})\end{array}$ & $\begin{array}{l}P_{g i}^{\max } \\
(\mathbf{M W})\end{array}$ & $\begin{array}{c}a_{i} \\
\left(\$ / \mathbf{M W}^{2}\right)\end{array}$ & $\begin{array}{c}\boldsymbol{b}_{\boldsymbol{i}} \\
(\$ / \mathbf{M} \\
\mathbf{W}) \\
\end{array}$ & $\begin{array}{c}c_{i} \\
(\$ / \mathbf{M W})\end{array}$ & $\begin{array}{c}D R_{i} \\
(\mathbf{M W} / \mathbf{h})\end{array}$ & $\begin{array}{c}U R_{i} \\
(\mathbf{M W / h})\end{array}$ & $\begin{array}{c}P_{g i}^{0} \\
(\mathbf{M W})\end{array}$ & $\begin{array}{l}\text { Prohibited operating zone } \\
\text { (POZ) }\end{array}$ \\
\hline 1 & 150 & 455 & 0,000299 & 10,1 & 671 & 120 & 80 & 400 & \\
\hline 2 & 150 & 455 & 0,000183 & 10,2 & 574 & 120 & 80 & 300 & $\begin{array}{l}{\left[\begin{array}{ll}185 & 225\end{array}\right]\left[\begin{array}{ll}305 & 335\end{array}\right]} \\
{[420450]}\end{array}$ \\
\hline 3 & 20 & 130 & 0,001126 & 8,8 & 374 & 130 & 130 & 105 & \\
\hline 4 & 20 & 130 & 0,001126 & 8,8 & 374 & 130 & 130 & 100 & \\
\hline 5 & 150 & 470 & 0,000205 & 10,4 & 461 & 120 & 80 & 90 & $\begin{array}{l}{\left[\begin{array}{ll}180 & 200\end{array}\right]\left[\begin{array}{ll}305 & 335\end{array}\right]} \\
{[390420]}\end{array}$ \\
\hline 6 & 135 & 460 & 0,000301 & 10,1 & 630 & 120 & 80 & 400 & $\begin{array}{l}{\left[\begin{array}{ll}230 & 255\end{array}\right]\left[\begin{array}{ll}365 & 395\end{array}\right]} \\
{\left[\begin{array}{lll}430 & 455\end{array}\right]}\end{array}$ \\
\hline 7 & 135 & 465 & 0,000364 & 9,8 & 548 & 120 & 80 & 350 & \\
\hline 8 & 60 & 300 & 0,000338 & 11,2 & 227 & 100 & 65 & 95 & \\
\hline 9 & 25 & 162 & 0,000807 & 11,2 & 173 & 100 & 60 & 105 & \\
\hline 10 & 25 & 160 & 0,001203 & 10,7 & 175 & 100 & 60 & 110 & \\
\hline 11 & 20 & 80 & 0,003586 & 10,2 & 186 & 80 & 80 & 60 & \\
\hline 12 & 20 & 80 & 0,005513 & 9,9 & 230 & 80 & 80 & 40 & 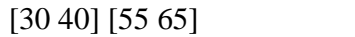 \\
\hline 13 & 25 & 85 & 0,000371 & 13,1 & 225 & 80 & 80 & 30 & \\
\hline 14 & 15 & 55 & 0,001929 & 12,1 & 309 & 55 & 55 & 20 & \\
\hline 15 & 15 & 55 & 0,004447 & 12,4 & 323 & 55 & 55 & 20 & \\
\hline
\end{tabular}

TABEL III. KARAKTERISTIK UNIT GENERATOR STUdI KASUS 3 
Januari - Juni 2021

$$
\begin{aligned}
& B=10^{-5} *\left[\begin{array}{ccccccccccccccc}
1,4 & 1,2 & 0,7 & -0,1 & -0,3 & -0,1 & -0,1 & -0,1 & -0,3 & -0,5 & -0,3 & -0,2 & 0,4 & 0,3 & -0,1 \\
1,2 & 1,5 & 1,3 & 0 & -0,5 & -0,2 & 0 & 0,1 & -0,2 & -0,4 & -0,4 & 0 & 0,4 & 1,0 & -0,2 \\
0,7 & 1,3 & 7,6 & -0,1 & -1,3 & -0,9 & -0,1 & 0 & -0,8 & -1,2 & -1,7 & 0 & -2,6 & 11,1 & -2,8 \\
-0,1 & 0 & -0,1 & 3,4 & -0,7 & -0,4 & 1,1 & 5,0 & 2,9 & 3,2 & -1,1 & 0 & 0,1 & 0,1 & -2,6 \\
-0,3 & -0,5 & -1,3 & -0,7 & 9,0 & 1,4 & -0,3 & -1,2 & -1,0 & -1,3 & 0,7 & -0,2 & -0,2 & -2,4 & -0,3 \\
-0,1 & -0,2 & -0,9 & -0,4 & 1,4 & 1,6 & 0 & -0,6 & -0,5 & -0,8 & 1,1 & -0,1 & -0,2 & -1,7 & 0,3 \\
-0,1 & 0 & -0,1 & 1,1 & -0,3 & 0 & 1,5 & 1,7 & 1,5 & 0,9 & -0,5 & 0,7 & 0 & -0,2 & -0,8 \\
-0,1 & 0,1 & 0 & 5,0 & -1,2 & -0,6 & 1,7 & 16,8 & 8,2 & 7,9 & -2,3 & -3,6 & 0,1 & 0,5 & -7,8 \\
-0,3 & -0,2 & -0,8 & 2,9 & -1,0 & -0,5 & 1,5 & 8,2 & 12,9 & 11,6 & -2,1 & -2,5 & 0,7 & -1,2 & -7,2 \\
-0,5 & -0,4 & -1,2 & 3,2 & -1,3 & -0,8 & 0,9 & 7,9 & 11,6 & 20 & -2,7 & -3,4 & 0,9 & -1,1 & -8,8 \\
-0,3 & -0,4 & -1,7 & -1,1 & 0,7 & 1,1 & -0,5 & -2,3 & -2,1 & -2,7 & 14,0 & 0,1 & 0,4 & -3,8 & 16,8 \\
-0,2 & 0 & 0 & 0 & -0,2 & -0,1 & 0,7 & -3,6 & -2,5 & -3,4 & 0,1 & 5,4 & -0,1 & -0,4 & 2,8 \\
0,4 & 0,4 & -2,6 & 0,1 & -0,2 & -0,2 & 0 & 0,1 & 0,7 & 0,9 & 0,4 & -0,1 & 10,3 & -10,1 & 2,8 \\
0,3 & 1,0 & 11,1 & 0,1 & -2,4 & -1,7 & -0,2 & 0,5 & -1,2 & -1,1 & -3,8 & -0,4 & -10,1 & 57,8 & -9,4 \\
-0,1 & -0,2 & -2,8 & -2,6 & -0,3 & 0,3 & -0,8 & -7,8 & -7,2 & -8,8 & 16,8 & 2,8 & 2,8 & -9,4 & 128,3
\end{array}\right] \\
& B 0=10^{-3} *\left[\begin{array}{lllllllllllllll}
-0.1 & -0.2 & 2.8 & -0.1 & 0.1 & -0.3 & -0.2 & -0.2 & 0.6 & 3.9 & -1,7 & 0 & -3.2 & 6.7 & -6.4
\end{array}\right] \\
& B 00=0,0055
\end{aligned}
$$

\section{HASIL DAN PEMBAHASAN}

Simulasi penyelesaian ED dengan metode EO diimplementasikan dengan menggunakan perangkat lunak MATLAB. Parameter-parameter yang digunakan untuk simulasi antara lain adalah: nilai parameter $a_{1}$ dan $a_{2}$ masingmasing adalah 2 dan 1 , nilai $G P$ adalah 0,5 , jumlah partikel adalah 50, dan jumlah iterasi maksimum adalah 500. Simulasi dilakukan sebanyak 30 kali untuk setiap studi kasus. Hasil simulasi untuk setiap studi kasus dijelaskan pada bagian selanjutnya.

\section{A. Studi Kasus 1}

Pada kasus ini, hasil penyelesaian ED menggunakan metode EO dibandingkan dengan hasil penyelesaian dengan menggunakan algoritma standar dari beberapa metode untuk penyelesaian ED antara lain, Simulasi penyelesaian ED dengan menggunakan metode PSO, GWO, dan WOA dilakukan dengan menggunakan jumlah iterasi maksimum dan jumlah partikel atau search agents yang sama dengan jumlah partikel yang digunakan untuk simulasi menggunakan metode EO.

Hasil penyelesaian terbaik dengan menggunakan metode EO dan metode perbandingan lainnya ditunjukkan pada Tabel IV. Dari Tabel IV, dapat dilihat bahwa penyelesaian masalah ED menggunakan metode EO sama baiknya dengan penyelesaian dengan metode-metode lainnya. Kurva konvergensi penyelesaian terbaik untuk studi kasus 1 dari semua metode ditunjukkan pada Gambar 4. Dari Gambar 4 dapat dilihat bahwa metode EO lebih cepat menemukan nilai fungsi objektif yang mendekati nilai minimumnya dibandingkan metode lainnya dengan jumlah iterasi yang

\begin{tabular}{|c|c|c|c|c|}
\hline \multirow[b]{2}{*}{ Metode } & \multicolumn{4}{|c|}{ Daya Output } \\
\hline & $\begin{array}{c}P_{g 1} \\
(\mathbf{M W})\end{array}$ & $\begin{array}{c}P_{g 2} \\
(\mathbf{M W})\end{array}$ & $\begin{array}{c}P_{g 3} \\
(\mathbf{M W})\end{array}$ & $\begin{array}{c}\text { Total } \\
\text { Biaya } \\
(\$ / h)\end{array}$ \\
\hline PSO & 393,170 & 334,604 & 122,226 & $8.194,356$ \\
\hline GWO & 393,170 & 334,601 & 122,229 & $8.194,356$ \\
\hline WOA & 393,170 & 334,603 & 122,228 & $8.194,356$ \\
\hline $\mathrm{EO}$ & 393,170 & 334,604 & 122,226 & $8.194,356$ \\
\hline
\end{tabular}
lebih sedikit.

TABEL IV. Penyelesaian Terbaik UnTUK StUdi Kasus 1

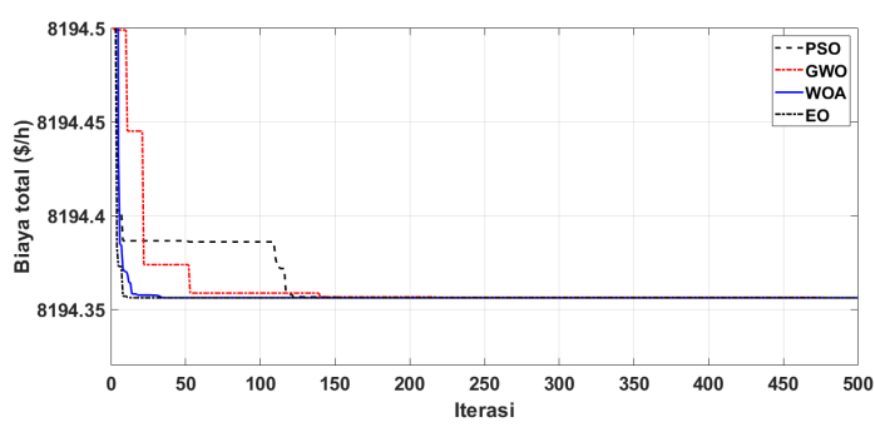

Gambar 4. Kurva konvergensi studi kasus 1

\section{B. Studi Kasus 2}

Hasil penyelesaian terbaik untuk studi kasus 2 dengan metode EO dan metode-metode PSO, GWO, dan WOA ditunjukkan pada Tabel V. Kurva konvergensi penyelesaian terbaik studi kasus 2 untuk semua metode ditunjukkan pada Gambar 5. Tabel V menunjukkan penyelesaian ED menggunakan metode-metode EO sama baiknya dengan penyelesaian ED menggunakan metode $\mathrm{PSO}, \mathrm{GWO}$, dan WOA. Sama seperti pada studi kasus 1, metode EO mampu konvergen ke nilai yang mendekati nilai minimum fungsi objektif lebih cepat dibandingkan metode-metode lainnya.

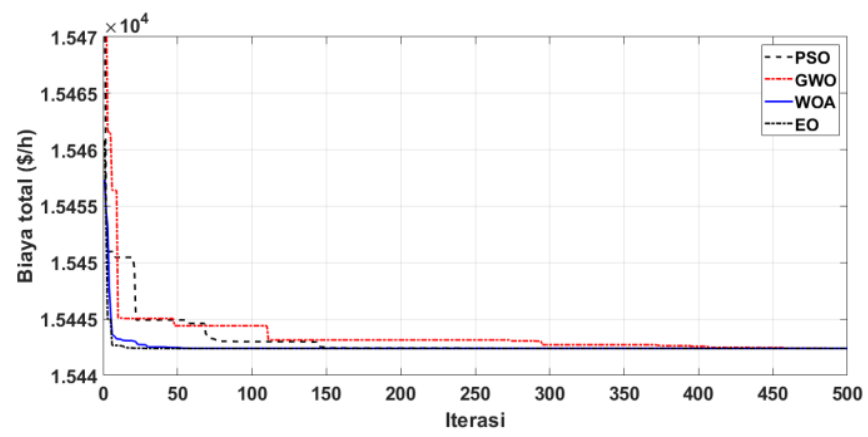

Gambar 5. Kurva konvergensi studi kasus 2

C. Studi Kasus 3

Hasil penyelesaian terbaik menggunakan metode EO dibandingkan dengan metode-metode PSO, GWO, dan WOA. Perbandingan hasil penyelesaian terbaik menggunakan 
metode EO dan metode lainnya ditunjukkan pada Tabel VI. Kurva konvergensi untuk studi kasus 3 ditunjukkan pada Gambar 6. Tabel VI dan Gambar 6 menunjukkan bahwa metode EO mempunyai penyelesaian yang lebih baik dan dapat lebih cepat konvergen ke nilai yang mendekati nilai fungsi objektif yang paling minimum dibandingkan dengan metode-metode penyelesaian ED lainnya.

Dari hasil simulasi untuk setiap kasus, metode EO dapat menyelesaikan permasalahan ED dengan nilai fungsi objektif yang paling minimum. Perbandingan kurva konvergensi untuk setiap studi kasus menunjukkan metode EO dapat lebih optimal menemukan nilai fungsi objektif yang mendekati nilai minimumnya dengan jumlah iterasi yang lebih sedikit. Analisis statistik dari 30 kali simulasi untuk setiap kasus dengan menggunakan semua metode ditunjukkan pada Tabel VII.
Nilai standar deviasi menyatakan perbedaan yang signifikan antara hasil penyelesaian minimum dengan hasil penyelesaian maksimum dari 30 kali simulasi. Semakin besar nilai standar deviasi, semakin besar pula perbedaan penyelesaian minimum dan maksimum yang diperoleh.

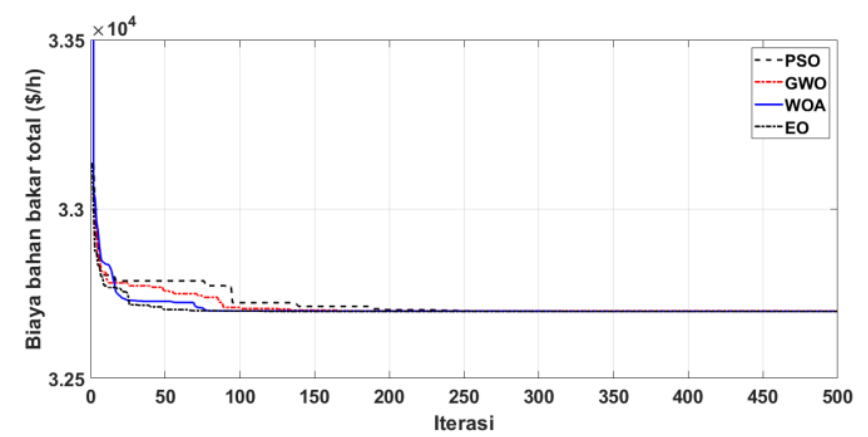

Gambar 6. Kurva konvergensi studi kasus 3

TABEL V. PENYElESAIAN TERBAIK UNTUK StUdi KASUS 2

\begin{tabular}{lrrrr}
\hline \hline $\begin{array}{c}\text { Daya output generator } \\
\text { dan total biaya } \\
\text { pembangkitan }\end{array}$ & \multicolumn{1}{c}{ PSO } & \multicolumn{1}{c}{ GWO } & \multicolumn{1}{c}{ WOA } & \multicolumn{1}{c}{ EO } \\
\cline { 2 - 5 }$\left(P_{g 1}(\mathrm{MW})\right.$ & 447,389 & 447,488 & 447,379 & 447,389 \\
$P_{g 2}(\mathrm{MW})$ & 173,233 & 173,2670 & 173,658 & 173,233 \\
$P_{g 3}(\mathrm{MW})$ & 263,374 & 263,313 & 263,072 & 263,374 \\
$P_{g 4}(\mathrm{MW})$ & 138,971 & 138,950 & 138,925 & 138,971 \\
$P_{g 5}(\mathrm{MW})$ & 165,384 & 165,343 & 165,453 & 165,384 \\
$P_{g 6}(\mathrm{MW})$ & 87,043 & 87,030 & 86,906 & 87,043 \\
Total Daya & $1.275,394$ & $1.275,393$ & $1.275,394$ & $1.275,394$ \\
Pembangkitan $(\mathrm{MW})$ & 12,394 & 12,393 & 12,394 & 12,394 \\
Rugi-rugi $(\mathrm{MW})$ & $15.442,393$ & $15.442,393$ & $15.442,396$ & $15.442,393$ \\
Total Biaya & & & & \\
Pembangkitan $(\$ / \mathrm{h})$ & &
\end{tabular}

TABEL VI. Penyelesaian Terbaik Untuk Studi Kasus 3

\begin{tabular}{|c|c|c|c|c|}
\hline \multirow{2}{*}{$\begin{array}{c}\text { Daya output } \\
\text { generator, total daya } \\
\text { output dan biaya } \\
\text { pembangkitan }\end{array}$} & \multicolumn{4}{|c|}{ Metode } \\
\hline & PSO & GWO & WOA & EO \\
\hline$P_{g 1}(\mathrm{MW})$ & 455,000 & 455,000 & 455,000 & 455,000 \\
\hline$P_{g 2}(\mathrm{MW})$ & 380,000 & 380,000 & 380,000 & 380,000 \\
\hline$P_{g 3}(\mathrm{MW})$ & 130,000 & 130,000 & 130,000 & 130,000 \\
\hline$P_{g 4}(\mathrm{MW})$ & 130,000 & 130,000 & 130,000 & 130,000 \\
\hline$P_{g 5}(\mathrm{MW})$ & 170,000 & 170,000 & 170,000 & 170,000 \\
\hline$P_{g 6}(\mathrm{MW})$ & 460,000 & 460,000 & 460,000 & 460,000 \\
\hline$P_{g 7}(\mathrm{MW})$ & 430,000 & 430,000 & 430,000 & 430,000 \\
\hline$P_{g 8}(\mathrm{MW})$ & 71,612 & 76,248 & 60,369 & 71,530 \\
\hline$P_{g 9}(\mathrm{MW})$ & 58,466 & 51,733 & 69,629 & 58,552 \\
\hline$P_{g 10}(\mathrm{MW})$ & 160,000 & 160,000 & 160,000 & 160,000 \\
\hline$P_{g 11}(\mathrm{MW})$ & 80,000 & 80,000 & 80,000 & 80,000 \\
\hline$P_{g 12}(\mathrm{MW})$ & 80,000 & 80,000 & 80,000 & 80,000 \\
\hline$P_{g 13}(\mathrm{MW})$ & 25,000 & 25,086 & 25,006 & 25,000 \\
\hline$P_{g 14}(\mathrm{MW})$ & 15,001 & 15,256 & 15,015 & 15,000 \\
\hline$P_{g 15}(\mathrm{MW})$ & 15,001 & 16,653 & 15,030 & 15,000 \\
\hline $\begin{array}{l}\text { Total Daya } \\
\text { Pembangkitan (MW) }\end{array}$ & $2.660,081$ & $2.659,972$ & $2.660,049$ & 2660,081 \\
\hline Rugi-rugi (MW) & 30,081 & 29,972 & 30,049 & 30,081 \\
\hline Total Biaya $(\$ / \mathrm{h})$ & $32.697,899$ & $32.698,939$ & $32.698,258$ & $32.697,899$ \\
\hline
\end{tabular}


TABEL VII. ANALISIS STATISTIK

\begin{tabular}{lrrrrr}
\hline \hline $\begin{array}{c}\text { Metode } \\
\text { dan }\end{array}$ & $\begin{array}{c}\text { Nilai } \\
\text { Studi } \\
\text { Kasus }\end{array}$ & minimum & $\begin{array}{c}\text { Nilai } \\
\text { maksimum }\end{array}$ & $\begin{array}{c}\text { Nilai } \\
\text { rata-rata }\end{array}$ & $\begin{array}{c}\text { Standa } \\
\mathbf{r} \\
\text { deviasi }\end{array}$ \\
\hline PSO & 1 & $8.194,356$ & $8.194,356$ & $8.194,356$ & 0.000 \\
& 2 & $15.442,393$ & $15.443,942$ & $15.442,451$ & 0,282 \\
& 3 & $32.697,899$ & $32.701,988$ & $32.698,220$ & 0,726 \\
GWO & 1 & $8.194,356$ & $8.194,356$ & $8.194,356$ & 0.000 \\
& 2 & $15.442,393$ & $15.442,393$ & $15.442,393$ & 0,000 \\
& 3 & $32.698,939$ & $32.798,426$ & $32.709,034$ & 22,374 \\
WOA & 1 & $8.194,356$ & $8.194,356$ & $8.194,356$ & 0.000 \\
& 2 & $15.442,396$ & $15.442,815$ & $15.442,433$ & 0,081 \\
& 3 & $32.698,258$ & $32.765,178$ & $32.724,312$ & 20,838 \\
EO & 1 & $8.194,356$ & $8.194,356$ & $8.194,356$ & 0,000 \\
& 2 & $15.442,393$ & $15.442,422$ & $15.442,407$ & 0,015 \\
& 3 & $32.697,899$ & $32.698,048$ & $32.697,935$ & 0,041 \\
\hline \hline
\end{tabular}

Dari Tabel VII dapat dilihat nilai standar deviasi dengan menggunakan metode EO untuk semua kasus bernilai lebih kecil dari 1. Hal ini berarti bahwa dari 30 kali simulasi, hasil penyelesaian setiap simulasi dengan metode EO lebih mendekati nilai minimumnya. Selain itu, untuk kasus di mana jumlah generator semakin besar (studi kasus 3), metode EO mampu tetap menghasilkan nilai fungsi objektif paling minimum dengan standar deviasi yang sangat kecil.

\section{PENUTUP}

Metode EO dapat dengan baik menyelesaikan permasalahan ED dengan fungsi biaya bahan bakar yang halus, baik dengan atau tanpa mempertimbangkan batasan-batasan operasi generator, seperti RR dan POZ. Nilai biaya bahan bakar total yang diperoleh menggunakan metode EO masingmasing adalah 8.194,356 \$/h untuk studi kasus 1, 15.442,393 $\$ /$ h untuk studi kasus 2, dan 32.697,899 \$/h untuk studi kasus 3 di mana merupakan nilai minimum dibandingkan dengan hasil penyelesaian menggunakan metode PSO, GWO, dan WOA. Dengan keunggulan dalam hasil penyelesaian nilai fungsi objektif yang paling minimum, kecepatan konvergensi, dan nilai standar deviasi, metode EO dapat menjadi salah satu pilihan untuk menyelesaikan permasalahan ED. Perbaikan dalam algoritma perlu dilakukan untuk meningkatkan penampilan metode EO dalam penyelesaian masalah ED dengan batasan-batasan maupun jumlah generator yang lebih banyak.

\section{REFERENSI}

[1] P. Shanshan, J. Jinbao, C. Huangyue, and Y. Linfeng, "A Full Mixedinteger Linear Programming Formulations for Economic Dispatch with Valve-point Effects, Transmission Loss and Prohibited Operating Zones," Electric Power System Research, vol. 180, pp. 1-12, 2020.

[2] M. Gholamghasemi, E. Akbari, M.B. Asadpoor, and M. Ghasemi, "A New Solution to the Non-convex Economic Load Dispatch Problems Using Phasor Particle Swarm Optimization," Applied Soft Computing Journal, vol. 79, pp. 111-124, 2019.

[3] S. M. A. Bulbul, M. Pradhan, P. K. Roy, and T. Pal, "Opposition-based Krill Herd Algorithm Applied to Economic Load Dispatch Problem," Ain Shams Engineering Journal, vol. 9, no. 3, pp. 423-440, 2018.

[4] M. Basu, "Kinetic Gas Molecule Optimization for Nonconvex Economic Dispatch Problem," International Journal of Electrical Power and Energy Systems, vol. 80, pp. 325-332, 2016.

[5] X. Shen, G. Wu, R. Wang, H. Chen, H. Li, and J. Shi, "A Self-Adapted Across Neighborhood Search Algorithm With Variable Reduction Strategy for Solving Non-Convex Static and Dynamic Economic Dispatch Problems," IEEE Access, vol. 6, pp. 41314-41324, 2018.

[6] M. M. Delshad, S. H. A. Kaboli, E. T. Renani, and N. A. Rahim, "Backtracking Search Algorithm for Solving Economic Dispatch Problem with Valve-point Effects and Multiple Fuel Options," Energy, vol. 116, pp. 637-649, 2016
[7] K. A. Alawode, A. M. Jubril, L. O. Kehinde, and P. O. Ogunbona, "Semidefinite Programming Solution of Economic Dispatch Problem with Non-Smooth, Non-Convex Cost Function," Electric Power System Research, vol. 164, pp. 178-187, 2018.

[8] D. Singh and J. S. Dhillon, "Ameliorated Grey Wolf Optimization for Economic Dispatch Problem," Energy, vol. 169, pp. 398-419, 2019.

[9] T. Jayabarathi, T. Raghunathan, B. R. Adarsh, and P. N. Suganthan, "Economic Dispatch Using Hybrid Grey Wolf Optimizer," Energy, vol. 111, pp. 630-641, 2016.

[10] Q. Zhang, D. Zhou, N. Duan, and X. Shen, “An Adaptive Differential Evolutionary Algorithm Incorporating Multiple Mutation Strategies for Economic Load Dispatch Problems,'Applied Soft Computing Journal, vol. 78, pp. 641-669, 2019.

[11] F. Mohammadi and H. Abdi, "A Modified Crow Search Algorithm (MCSA) for Solving Economic Load Dispatch Problem," Applied Soft Computing, vol. 71, pp. 51-65, 2018.

[12] D. C. Secui, "A Modified Symbiotic Organisms Search Algorithm for Large Scale Economic Dispatch Problem with Valve-point Effects," Energy, vol. 113, pp. 366-384, 2016.

[13] P. Zakian, and A. Kaveh, "Economic Dispatch of Power Systems Using an Adaptive Charged System Search Algorithm," Applied Soft Computing, vol. 73, pp. 607-622, 2018.

[14] V. K. Kamboj, A. Bhadoria, and S. K. Bath, "Solution of Non-convex Economic Load Dispatch Problem for Small-scale Power Systems Using Ant Lion Optimizer," Neural Computing. Application, vol. 28, no. 8, pp. 2181-2192, 2017.

[15] T. Sen and H. D. Mathur, "A New Approach to Solve Economic Dispatch Problem Using a Hybrid ACO-ABC-HS Optimization Algorithm," International Journal of Electrical Power and Energy System, vol. 78, pp. 735-744, 2016.

[16] A. A. Elsakaan, R. A. El-Sehiemy, S. S. Kaddah, and M. I. Elsaid, "An Enhanced Moth-flame Optimizer for Solving Non-smooth Economic Dispatch Problems with Emissions," Energy, vol. 157, pp. 1063-1078, 2018.

[17] S. C. Cui, Y. W. Wang, X. N. Lin, and X. K. Liu, "Distributed auction optimization algorithm for the nonconvex economic dispatch problem based on the gossip communication mechanism,'International Journal of Electrical Power and Energy System, vol. 95, pp. 417-426, 2018.

[18] M. Basu, "Fast Convergence Evolutionary Programming for Economic Dispatch Problems," IET Generation, Transmission and Distribution, vol. 11, no. 16, pp. 4009-4017, 2017.

[19] B. R. Adarsh, T. Ragunathan, T. Jayabarathi, and X. S. Yang, "Economic Dispatch Using Chaotic Bat Algorithm," Energy, vol. 96, pp. 666-675, 2016.

[20] M. Abdel-Basset, R. Mohamed, S. Mirjalili, R. K. Chakrabortty, and M. J. Ryan, "Solar Photovoltaic Parameter Estimation Using an Improved Equilibrium Optimizer," Solar Energy, vol. 209, pp. 694-708, 2020.

[21] J. Too and S. Mirjalili, "General Learning Equilibrium Optimizer: A New Feature Selection Method for Biological Data Classification," Applied Artificial Intelligence, vol. 35, no. 3, pp. 247-263, 2021.

[22] A. D. Tang, T. Han, H. Zhou, and L. Xie, "An Improved Equlibrium Optimizer with Application in Unmanned Aerial Vehicle Path Planning," Sensors, vol. 21, no. 1814, pp. 1-21, 2021.

[23] J. Kennedy and R. Eberhart, "Particle Swarm Optimization," in Proceedings of the IEEE International Conference on Neural Networks, vol. 4, pp. 1942-1948, 1995.

[24] W. T. Elsayed, Y. G. Hegazy, M. S. El-bages, and F. M. Bendary, "Improved Random Drift Particle Swarm Optimization with SelfAdaptive Mechanism for Solving the Power Economic Dispatch Problem," IEEE Transaction on Industrial Informatics, vol. 13, no. 3, pp. 1017-1026, 2017.

[25] S. Mirjalili, S. M. Mirjalili, and A. Lewis, "Grey Wolf Optimizer," Advances in Engineering Software, vol. 69, pp. 46-61, 2014.

[26] M. Pradhan, P. K. Roy, and T. Pal, 'Grey Wolf Optimization Applied to Economic Dispatch Problems," International Journal of Electrical Power and Energy System, vol. 83, pp. 325-334, 2016.

[27] S. Mirjalili, and A. Lewis, "The Whale Optimization Algorithm," Advances in Engineering Software, vol. 95, pp. 51-67, 2016.

[28] Y. Wu, G. Liu, X. Guo, Y. Shi, and L. Xie, "A self-adaptive chaos and Kalman flter-based particle swarm optimization for economic dispatch problem," Soft Computing, vol. 21, no. 12, pp. 3353-3365, 2017.

[29] A. Faramarzi, M. Heidarinejad, B. Stephens, and S. Mirjalili, "Equilibrium Optimizer: A Novel Optimization Algorithm,' Knowledge-based Systems, vol. 191, no. 105190, pp. 1-39, 2019.

[30] Z. L. Gaing, "Particle Swarm Optimization to Solving the Economic Dispatch Considering the Generator Constraints," IEEE Transaction on Power Systems, vol. 18, no. 3, pp. 1187-1195, 2003. 